\title{
MINIREVIEW
}

\section{Taxonomy of the Genus Frankia (Actinomycetales)}

\author{
MARY P. LECHEVALIER $\dagger$ \\ Waksman Institute of Microbiology, Rutgers, The State University of New Jersey,
} Piscataway, New Jersey 08855-0759

\begin{abstract}
Members of the genus Frankia have been classified in the order Actinomycetales on the basis of morphology, cell chemistry, and 16S rRNA sequences and catalogs. This genus, which is presently defined by morphology, cell chemistry, the ability to fix nitrogen, and infectivity for and ability to enter into symbiotic relationships with certain plant hosts, may be heterogeneous. Frankia species groups have been difficult to delineate by classical phenotypic methods. The recent use of DNA-DNA pairing and low-frequency restriction fragment analysis, as well as probes composed of certain sequences from the nif (nitrogen fixation) genes or the variable regions of 16S rRNA, has contributed to substantial progress in developing species concepts. In this review I trace the taxonomic history of the genus and outline some of the problems to be resolved in the future.
\end{abstract}

Frankiae are nitrogen-fixing actinomycete symbionts that cause the formation of perennial nodules on the roots of a botanically diverse group of bushes and small trees belonging to eight families, 25 genera, and well over 200 species. The association is referred to as "actinorhizal." A number of good recent reviews $(9,10,15)$ provide an overview of the Frankia-plant interaction. The frankiae themselves are relative newcomers to laboratory research, and their taxonomy is still developing.

From an evolutionary standpoint, actinorhizal associations are quite old; there is fossil evidence of actinomycetecontaining nodules on alders in the late Pleistocene era (5). As early as $1866(52,100)$ it was hypothesized that the endophyte is microbial, but this was proven only after the introduction of electron microscopy and the actual isolation and maintenance of a pure culture in 1978 (21).

In 1970, despite his lack of success in growing a single strain in vitro, and believing the organisms to be obligate symbionts, J. H. Becking (11) proposed that the name Frankia should be resurrected for these organisms. The name had been first proposed by Brunchorst in 1886 (20) to honor A. B. Frank, a Swiss microbiologist who coined the word symbiosis, but had fallen into disuse. Becking correctly discerned the actinomycetic nature of the endophytes and placed them in the family Frankiaceae in the order Actinomycetales. Following the lead of Rhizobium taxonomists, he created 10 species on the basis of host plant specificity, which he determined by using crushed nodules as inocula.

Following the successful propagation of the first isolate, more and more strains became available, and problems of nomenclature and taxonomy became a matter of concern, especially as Becking's host compatibility data were not always found to be correct (49). The slow growth and nutritional fastidiousness of Frankia isolates made it difficult to pursue classical phenotypic approaches to the taxonomy of these organisms, and molecular methods have proven to be increasingly useful. Indeed, from a methodological point of view, the current taxonomic research on Frankia isolates might be said to be a paradigm for microbial taxonomy in

† Present address: RR 2, Box 2235, Morrisville, VT 05661. general. In this review I trace the development and present the status of the taxonomy of the genus and try to predict what the future may hold.

Phylogeny. Unlike the leguminous plants with which rhizobia form symbiotic nitrogen-fixing associations (24), actinorhizal plants are thought to be polyphyletic in origin (65). Thus, the basis for and understanding of the Frankia-plant symbiosis must be sought at the molecular or biochemical level. Unlike their plant hosts, frankiae have been assumed to be a phylogenetically homogeneous group on the basis of a variety of phenotypic characteristics, including morphology, cell chemistry, and nitrogen-fixing capacity. A comparison of sequences and catalogs of certain regions of $16 \mathrm{~S}$ rRNAs by Stackebrandt and his associates $(39,93)$ showed that two type " $B$ " frankiae (see below) could be shown to belong to one of the major sublines of descent of the Actinomycetales and to be closely related to members of the actinomycete genus Geodermatophilus. These authors redescribed the family Frankiaceae to include both the genus Frankia and the genus Geodermatophilus. The 16S rRNA sequences of type "A" strains have yet to be determined. Other workers found that sequencing of the rRNA genes of a single Frankia strain showed that the $5^{\prime}$-to-3' order is 16S-23S-5S, which is typical of bacteria in general (71).

Additional phylogenetic data were obtained from a study of 1 of the 20 or so genes which code for the enzymes involved in nitrogen fixation. The nifH gene, which codes for the iron protein component of nitrogenase, is very highly conserved; thus, it has been proposed that sequence data for this gene from a variety of nitrogen-fixing bacteria should be used in the construction of bacterial phylogenies (101). Interestingly, a determination of the sequences of the nifH genes of two frankiae $(70,74)$ showed that these organisms group with cyanobacteria of the genus Anabaena rather than with Clostridium pasteurianum, a gram-positive bacterium to which they are more closely related on the basis of $16 \mathrm{~S}$ rRNA sequences. Sequencing of the nifD gene of one of the same isolates showed that it clustered with both the genus Anabaena and the genus Klebsiella (72).

Taxonomy of the genus. When Becking proposed the genus Frankia (11), he could only hypothesize that the members of this genus were actinomycetes because of his lack of success in cultivating any of them in vitro. He based his conclusion 
on the gram-positive reactions of the organisms, as well as their hyphal nature and dimensions, their lack of a nuclear membrane, and the formation of what he called "terminal swellings," which he felt had morphological affinities to actinomycete conidia. (Also called "vesicles," these structures are now known to be the site of nitrogenase activity [59].) He also described the polyhedral cells that he observed within the plant cells, which are now known to be the sporangiospores of the organisms, but he did not observe the sporangia themselves. Later (12), he published data on the cell chemistry of the endophyte cells. Unfortunately, these data were incorrect since Becking analyzed material that was highly contaminated with plant debris.

Morphology is still one of the most important criteria for determining the generic status of actinomycetes, and this is true for the genus Frankia as well. Frankiae growing in artificial media produce the same general morphological structures that they produce in planta, including sparsely branched hyphae, vesicles (stipitate, round to oblong cells borne laterally on the hyphae), and multilocular sporangia containing nonmotile spores. The sporangiospores are unique among actinomycetes, because they are surrounded by multiple membranous layers visible by electron microscopy (52). Vesicle formation in some strains can be induced only in nitrogen-free media; in other strains vesicles are formed under all growth conditions. In the nodules, hyphae and vesicles are the most prominent features; in some cases many sporangia are also formed. Nodules containing many sporangia are referred to as "spore positive" $\left(\mathrm{Sp}^{+}\right)$, and the frankiae in these nodules may be more difficult to isolate and grow in vitro $(47,73)$. It is not known whether the $\mathrm{Sp}^{+}$ characteristic has taxonomic value. This is because actinomycetes vary enormously in their capacity to express morphological features and, unlike fungi, this expression is often very dependent on the nutritional or physical conditions of growth.

In recent years cell chemistry has played a prominent role in the taxonomy of actinomycetes at the generic level. The compounds that are important include the amino acids, amino sugars, and sugars present in the cell wall, cellular polysaccharides not covalently linked to the wall, fatty acids (especially those such as mycolic acids), phospholipids, and menaquinones (53). From the standpoint of cell chemistry, frankiae have both common and novel compositions (55). The cell wall composition type is type III (meso-diaminopimelic acid, glutamic acid, alanine, glucosamine, and muramic acid), the simplest and most common type found in the actinomycetes. In contrast, the whole-cell sugar (WCS) patterns are both diverse and (in some cases) novel. Most isolates have a type D WCS pattern (the diagnostic constituent is xylose, but the minor arabinose component found in other actinomycetes is not present). Other strains contain fucose (type E WCS pattern), a sugar not found in the polysaccharides of other actinomycetes; some isolates contain 3- $O$-methyl-D-galactose (madurose) (type B WCS pattern) or simply major amounts of galactose or glucose (type $\mathrm{C}$ WCS pattern). Most frankiae also contain 2- $O$-methylmannose $(63,80)$. The fatty acids are generally the normal and branched-chain types typical of most actinomycetes; mycolic acids are not present. The phospholipid pattern type is type PI (phosphatidylinositol, phosphatidylinositol mannosides, and diphosphatidylglycerol). The major menaquinones include MK-9 $\left(\mathrm{H}_{4}\right)$, MK-9( $\left.\mathrm{H}_{6}\right)$, and MK-9 $\left(\mathrm{H}_{8}\right)(82)$. The $\mathrm{G}+\mathrm{C}$ content ranges from 66 to $71 \mathrm{~mol} \%$ (as determined by the thermal denaturation method) (4).

Nitrogenase is an enzyme which is sensitive to oxygen. In
Frankia vesicles, the site of nitrogen fixation, protection against oxygen toxicity is provided by the buildup of lipidcontaining layers at the surface of the vesicles at a high partial $\mathrm{O}_{2}$ pressure (77). Freeze fracturing and sectioning have been used to demonstrate this unique feature $(40,77)$. A recent study (16) has demonstrated that major amounts of bacteriohopanetetrol $\left(\mathrm{C}_{35} \mathrm{H}_{62} \mathrm{O}_{4}\right)$ are present in extracts of cells of frankiae grown in vitro and in endophyte-containing nodule tissue, but not in host plant tissue alone. However, it is not known whether this lipid is the lipid at the surface of the vesicles because no increase in the amount of the compound was observed in cells grown under high oxygen tensions. However, this characteristic may be a good taxonomic marker if it is shown to be unique to Frankia spp. among the actinomycetes.

Frankiae are microaerophilic to reluctantly aerobic. Because many strains cannot be maintained on the surfaces of solid media, they are routinely grown in liquid media. They grow very slowly, and many isolates have having doubling times of 2 to 3 days or more. A few strains have a shorter doubling time (1 day, which approaches the growth rate of some of the slowly growing actinomycete saprophytes). Although frankiae are exacting in their growth requirements, they do not need complex media to grow well. A simple salts solution supplemented with an organic acid such as pyruvate or propionate as a carbon source often is sufficient since frankiae can fix nitrogen in vitro (55). The ability to fix nitrogen is considered a marker for the genus since nonnitrogenase-producing (nif) isolates are rare $(70,74)$. Recent reports $(33,45)$ of nitrogen fixation by certain Streptomyces isolates have shown that there may be problems with this characteristic; however, there is evidence that the enzymatic system involved in the Streptomyces isolates differs from the system of frankiae.

Two suprageneric or subgeneric groups have been proposed $(51,54)$ on the basis of physiology. Type A strains are quite diverse and in many cases not very different from slowly growing saprophytic actinomycetes. These organisms are relatively aerobic, and most can be maintained on slants. They are active physiologically, grow more rapidly than type B strains (see below), and utilize a variety of monosaccharides and disaccharides with or without acid production. Many produce hydrolytic enzymes, such as pectinases, cellulases, amylases, and proteases. They do not reinfect the host plants from which they were isolated, at least under the experimental conditions that are used at the present time.

In contrast, the members of the second group (type B) grow slowly (doubling times, 2 to 7 days) and are inactive physiologically, not utilizing (with few exceptions) carbohydrates, proteins, or starch. The preferred carbon sources include organic acids or Tween compounds. When Tween 80 is added to media containing certain carbohydrates, it has a synergistic effect on growth, and the dry cell weight of the test organism exceeds the sum of the cell weights of the organism grown separately on each carbon source. The type $B$ strains are strictly microaerophilic and cannot be maintained on slants, and they can infect the host plants from which they were isolated. Other types that differ from these two types probably exist (56).

The "constant" (relatively invariable for all taxa) regions of the 16S rRNA nucleotide sequences of actinomycetes are valuable for determining the proper placement of genera within the order Actinomycetales and for discerning the position of the order Actinomycetales in the Procaryotae, while it is widely believed that the "hypervariable" regions may help in phylogenetic classification at the genus or 
species level $(41,60)$. However, efforts to utilize the differences for Frankia taxonomy at the genus level have met with mixed success. For example, the sequences of one region (positions 1020 to 1042; Escherichia coli numbering) were found to differ when the rRNAs of effective (nitrogenfixing) and ineffective Frankia strains were compared (37). With one exception, probes containing 20 to 22 nucleotides targeting this region did not cross-react with the rRNAs of the other actinomycetes tested. The organisms that did not react included representatives of the genera Streptomyces, Streptoverticillium, Actinomyces, Propionibacterium, Pimelobacter, Terrabacter, Tsukamurella, Nocardiopsis, Caseobacter, Dermatophilus, and Geodermatophilus. However, both types of probes (probes from effective "EFP" and ineffective "IFP" types of Frankia) reacted with the rRNA of Nocardioides albus and thus could not be considered specific for the genus Frankia. Furthermore, the EFP probe reacted specifically with pure rRNAs from effective Frankia isolates obtained from Alnus spp. host plants but not with RNAs from effective isolates obtained from other plant hosts or ineffective Alnus strains. Thus, the authors concluded that the method might have only very limited value in taxonomy (37).

A sequence in the region from position 180 to position 240 (E. coli numbering) was exploited as a probe by Hahn et al. (38). This probe was found to react with all 23 Frankia strains tested, but at higher temperatures some strains no longer hybridized, indicating that their sequences differed from the sequences of the other strains. When representatives of 22 other actinomycete genera were tested, the Actinomadura and Microbispora strains reacted positively, further indicating the lack of specificity of the probe. When the utility of other probes from other regions (positions 140 to 220,430 to 540 , and 980 to 1060 ) was examined, the probes were also found to be not specific at the generic level, since type A and B Frankia strains reacted differently. It was also found that sequences from $E$. coli positions 1 to 925 reacted differently with different Frankia strains.

Simonet et al. (88) tackled the problem of a genus-specific probe by using a different approach. Two different sets of primers were designed, a universal set targeted to nine nitrogen-fixing microbial genera but giving negative results with organisms that do not fix nitrogen and another set which was specific for the nifH-nifD regions of Frankia spp. With PCR, amplification of the DNAs of various Frankia strains with the two primer sets gave rise to fragments whose lengths were specific for the genus. In the same way, universal and specific primers targeted to the 16S rRNA gene region were prepared. With the specific primers the specific sizes of the fragments generated were characteristic of Frankia spp. and also of the closely allied genus Geodermatophilus and were therefore presumably specific for members of the family Frankiaceae. In order to separate members of the genus Geodermatophilus from members of the genus Frankia, two additional primers were designed, which took advantage of the differences in size of the sequence that separates (intergenic sequence [IGS]) the 16S and 23S rRNA genes. Following amplification, the sizes of the Frankia fragments that were generated centered around 561 bp and differed from the sizes of the fragments generated from Geodermatophilus strains and the other microorganisms tested. This promising system has yet to be tested with a large number of strains belonging to various actinomycete taxa, a difficult but feasible task.

Taxonomy of the species. Becking's proposed species (11) were inadequate because (i) his host ranges were not always correct when they were determined by using pure strains; (ii) nodules often contain more than one endophyte strain (18, $35,47,67$ ) and these strains may not be related to each other; (iii) some isolates cannot be shown to be infective for their original host under a variety of greenhouse conditions; and (iv) not all strains that infect the same host plant species are similar enough by today's standards to be placed in the same species.

The unexpected diversity of Frankia strains isolated from the same plant host has been amply confirmed and is based on morphological, physiological, biochemical, cell chemical, genetic, and serological differences $(14,27-29,43,51,56,57$, $67,73,84,92,97,102)$. Thus, simple isolation from a given plant host is not a sufficient basis for assignment to a species. Nevertheless, it has been shown by a variety of techniques, including DNA-DNA relatedness analysis, low-frequency restriction fragment analysis (LFRFA), and 16S rRNA gene sequencing (see below), that there are numerous natural groups among isolates obtained from the same host plant which may be equated with species.

Initial efforts to delineate Frankia species among the various isolates included the classical tests used in actinomycete classification $(36,62,85,99)$. These efforts were not successful, partly because the slow growth and metabolic inactivity of many of the organisms made these determinations difficult and because the results did not allow reliable discrimination of species $(54,82,97)$. It was agreed by workers in the field that, until better criteria for species definition could be found, the use of species names would be avoided. Instead, numerical designations describing the host plant of origin and a culture collection acronym were to be used $(48,49)$. Subsequently, various approaches to characterization were tried in an effort to construct meaningful groups at the species level. The characteristics examined included morphological differences, such as the sporangium formation in planta discussed above $(73,95)$; physiology of carbohydrate uptake $(51,56)$; utilization of various substrates and enzyme production $(30,42,84)$; serology $(7,51)$; host specificity $(8,19,23,26)$; isozyme patterns $(13,58)$; whole-cell sugar chemistry (50); polypeptide patterns (14); fatty acid contents $(61,98)$; restriction patterns $(2,18,25)$; restriction fragment length polymorphisms $(6,28,69)$; and DNA-DNA relatedness (3).

These studies revealed potentially useful taxonomic techniques, but the relationships of the various groups that resulted were difficult to discern because the strains studied were often few, were from limited provenances, and differed from study to study.

Lalonde and his colleagues investigated Frankia isolates obtained from plants belonging to the Rhamnaceae, Myricaceae, and Elaeagnaceae growing in North America. These authors looked at polypeptide patterns $(35,86)$, sugar analysis data (94), fatty acid data (87), isozyme data (34), speed of nodulation (68), competitiveness with other strains (86), the ability to fix nitrogen in planta (73), plasmids $(75,91)$, and nif sequences (74). Some of the data supported the idea that the host plant of origin is an important element in the separation of Frankia strains into species groups. Consequently, Lalonde et al. (46) proposed a redefinition of Becking's species Frankia alni and Frankia elaeagnii. F. alni was described with two subspecies, " $F$. alni subsp. pommerii" and " $F$. alni subsp. vandijkii," which represent the $\mathrm{Sp}^{-}$and $\mathrm{Sp}^{+}$types of isolates from plants of the genus Alnus, respectively. The type species of the genus, $F$. alni subsp. alni, has yet to be described in modern terms, and a type strain has not been selected (17). 
TABLE 1. Genomic Frankia species as determined by various DNA-DNA relatedness studies

\begin{tabular}{|c|c|c|c|c|}
\hline \multirow[b]{2}{*}{$\begin{array}{l}\text { Plant host } \\
\text { taxon }\end{array}$} & \multicolumn{2}{|c|}{ No. of Frankia isolates: } & \multirow[b]{2}{*}{$\begin{array}{l}\text { No. of genomic } \\
\text { species } \\
\text { discerned }\end{array}$} & \multirow[b]{2}{*}{ Reference } \\
\hline & $\begin{array}{c}\text { Clustered at a } \\
\text { relatedness } \\
\text { level of } \\
>70 \%^{a}\end{array}$ & Ungrouped & & \\
\hline \multirow[t]{3}{*}{ Alnus } & 8 & 2 & 1 & 3 \\
\hline & 12 & 6 & 3 & 31 \\
\hline & 16 & 1 & 5 & 1 \\
\hline \multirow[t]{3}{*}{ Casuarinaceae } & 2 & 3 & 1 & 3 \\
\hline & 7 & 3 & 1 & 31 \\
\hline & 5 & 0 & 1 & 83 \\
\hline \multirow[t]{3}{*}{ Elaeagnaceae } & 0 & 3 & 0 & 3 \\
\hline & 11 & 2 & 5 & 31 \\
\hline & 7 & 3 & 4 & 1 \\
\hline Myrica & 4 & 11 & 1 & 18 \\
\hline Podocarpus & 2 & 0 & 1 & 83 \\
\hline
\end{tabular}

${ }^{a}$ Genomic species in reference 1 were clustered at a level of relatedness of $>60 \%$.

DNA-DNA relatedness is currently believed to be one of the best methods to assess relationships among strains at the species level. The first group of workers to use this technique to study Frankia strains (3) found high levels of relatedness among most of the isolates obtained from Alnus spp. but no clear-cut patterns of relatedness among isolates obtained from Casuarina, Ceanothus, Elaeagnus, and Purshia spp. Fernandez et al. (31) identified three genomic species among 14 strains obtained from Alnus spp.; one of these species corresponded to " $F$. alni subsp. pommerii" of Lalonde et al. (46), and another corresponded to " $F$. alni subsp. vandijkii" of these same workers. Five genomic species were found among 12 isolates obtained from members of the Elaeagnaceae, and one genomic species comprised nine isolates obtained from members of the Casuarinaceae. Some strains were not grouped. Benson and Silvester (15) have pointed out that the finding of Fernandez et al. (31) that the type strain of " $F$. alni subsp. vandijkii" was related at a level of only $2 \%$ to the type strain of " $F$. alni subsp. pommerii"' suggests that these two taxa may represent distinct species groups. Also, the DNA-DNA relatedness data summarized in Table 1 emphasize the fact that the proposal of Lalonde et al. (46) did not go far enough and that additional species need to be described.

Akimov and Dobritsa (1) have argued that groups defined by morphology in planta $\left(\mathrm{Sp}^{+}\right.$and $\left.\mathrm{Sp}^{-}\right)$, physiology (types $\mathrm{A}$ and $B$ ), serology, and whole-cell sugar patterns were not sufficiently discriminatory at the species level but were, instead, supraspecific. Whole-cell polypeptide patterns were considered infraspecific, and fatty acid and isozyme patterns were not judged to be compatible with groups based on other criteria.

Fernandez and her colleagues (32) subsequently sequenced a 274-bp region of an rRNA operon (hypervariable region E2) from various Frankia strains obtained from plants of the genus Alnus, the family Elaeagnaceae, and the family Casuarinaceae. The sequences of the isolates obtained from Alnus spp. representing the three genomic species discerned in the DNA-DNA relatedness study (31) differed from each other, thus confirming the separation of these organisms. However, the ribosomal sequences of several isolates obtained from members of the Elaeagnaceae were almost identical even though the DNA-DNA hybridization data supported the division of these organisms into three genomic species. The authors concluded that the high degree of conservation of the $16 \mathrm{~S}$ rDNA sequences in this region accounted for the lack of discrimination.

In contrast, using a specific PCR-amplified, 268-bp DNA segment of the $16 \mathrm{~S}$ rRNA gene $(E$. coli positions 921 to 1189), Nazaret et al. (66) compared frankiae representing the nine genomic species of Fernandez et al. determined by DNA-DNA relatedness (31). With one exception, the data showed that strains belonging to the same genomic species had identical sequences and that they differed from the other genomic species. Thus, the choice of the 16S rRNA region studied is critical to the taxonomic value of the results obtained.

An evolutionary distance analysis by the same workers (66) showed that genomic species 1 of Fernandez et al. (" $F$. alni subsp. pommerii") branched closer to the isolates obtained from Casuarina spp. than to the other genomic species obtained from Alnus spp. This was true regardless of the analytical method used. Nazaret et al. also found that isolates obtained from Casuarina spp. which do not infect their original hosts but do infect Elaeagnus spp. branched closer to either isolates obtained from Casuarina spp. or isolates obtained from Elaeagnus spp. depending on the method of analysis. A Frankia isolate obtained from Purshia tridentata was at some distance from all of the other Frankia isolates, and Streptomyces ambofaciens was very distant from all of the Frankia strains studied.

Another approach to the definition of species involved restriction fragment length polymorphisms probed with sequences from the various genes coding for the nitrogenase enzyme complex (nif $A B$, nifD, nifK, and nifH) (67). Infective isolates obtained from Casuarina spp. exhibited highly homologous results regardless of the restriction enzyme used. However, noninfective strains differed from the first group and among themselves. In contrast, in a different study by other workers (1), both infective and noninfective isolates obtained from Alnus spp. exhibited high levels of DNADNA relatedness. Thus, infectivity may or may not have taxonomic value depending on the plant source of the strain. In this regard, it should be noted that nif probes may not always produce similar results even in closely related strains. Simonet et al. (92) reported that restriction fragment length polymorphisms of infective isolates obtained from Alnus spp. from the same provenance were alike when they were probed with nifHDK, whereas when they were probed with nif $A B$, five groups were found. Clearly, the last word has not been said on this.

The nifD-K DNA IGS in Frankia spp. is larger and more variable than the nifH-D IGS; thus, it was thought that the nifD-K IGS might be useful for distinguishing among closely related strains in PCR restriction fragment length polymorphism analyses. Using two primers composed of sequences from conserved nifD and nifK regions flanking the nifD-K IGS, Jamann et al. (44) found that the DNAs of Frankia isolates obtained from members of the Elaeagnaceae and Casuarinaceae could be amplified to yield a product of about $1,380 \mathrm{~kb}$. The DNAs of isolates obtained from Alnus spp. were amplified only weakly or were not amplified. Depending on the stringency of the conditions, either only frankiae or both frankiae and other nitrogen-fixing organisms yielded products. When the products were digested with various restriction enzymes, HinfI grouped together all of the test isolates obtained from members of the Elaeagnaceae, whereas MspI and ScfrI resolved these organisms into the genomic species groups previously determined by DNA- 
DNA pairing. Other enzymes gave strain-specific patterns. Isolates obtained from members of the Casuarinaceae were also clearly distinguished from isolates obtained from members of the Elaeagnaceae.

LFRFA has recently been used in an attempt to clarify the Frankia species problem (17). In this analysis, DNA was restricted by enzymes having few recognition sites in the genome of interest, and the resulting high-molecular-weight fragments were separated by pulsed-field electrophoresis. The sizes of the fragments were calculated, and the data were subjected to a numerical analysis. A total of 104 Frankia strains were studied, and 15 clusters at a similarity level of $>75 \%$ were dominated either by isolates obtained from Alnus spp. and members of the Myricaceae or by isolates obtained from members of the Casuarinaceae. These LFRFA findings lend weight to the conclusions of Lalonde et al. (46), the conclusions of the DNA-DNA relatedness studies (31), and some of the $16 \mathrm{~S}$ ribosomal DNA sequence data (66) which indicated that the host plant of origin is an important element in defining species. The results of the LFRFA study also confirmed the finding of Nazaret et al. (66) that the type strain of " $F$. alni subsp. pommerii" clusters at some distance from the other Frankia genomic species isolated from Alnus spp.

It is evident from the results described above that knowledge of the genes that control the Frankia-plant relationship is probably critical to the full development of a proper species concept for the genus. The so-called nod genes, which are instrumental in the instigation, development, and maintenance of nodules, are central among these. Attempts to complement nod mutants of rhizobia with Frankia nod genes have met with mixed success $(22,78)$. Probes containing nod genes from Rhizobium or Bradyrhizobium isolates do not give reproducible results with Frankia DNA libraries. However, a pectate lyase gene probe from Erwinia chrysanthemi yielded evidence that there were similar DNA sequences in Frankia isolates $(64,81,89)$. As this enzyme should be important in the infection process, it may ultimately be useful as a marker for species recognition.

Conclusions. Frankia taxonomy now seems on secure ground in some areas. Phylogenetically, all current data point to proper placement of the genus Frankia in the order Actinomycetales. Even the ability of Frankia isolates to fix nitrogen is apparently not unique but may be shared by certain Streptomyces species $(33,45)$. As indicated above, the genus Frankia itself is defined by a combination of morphology, cell chemistry, symbiotic capability, and nitrogenase production. It may be possible to obtain genusspecific probes based on intergenic sequences as well as probes that target nitrogen-fixing enzymes. Species are increasingly seen to be defined on the basis of host plant of origin, DNA-DNA relatedness data, and LFRFA analysis data. Workers may develop species-specific probes based on certain hypervariable regions of $16 \mathrm{~S}$ rRNA, and recognition of specific strains based on protein patterns (86), production of various isozymes (79), restriction patterns $(2,17,18,27)$, and $r m$ (76) and nif (90) sequences may be possible.

What remains to be done? In the ongoing process of clarifying Frankia taxonomic concepts, the various groups of workers involved should agree to study a common group of strains obtained from locales and plant hosts that are as diverse as possible. It is clear that there is a high probability that a consensus concerning species definitions will grow out of molecular studies of intergenic or hypervariable $16 \mathrm{~S}$ rRNA sequences, DNA-DNA relatedness analyses, and LFRFA, but such a consensus is difficult when each group of workers studies a different set of strains. From the $16 \mathrm{~S}$ rRNA sequencing and catalog data the phylogenetic position of the genus Frankia among the actinomycetes is clear, and the close relationship of type B frankiae to members of the genus Geodermatophilus has been demonstrated (39). Many other actinomycete genera still need to be positioned phylogenetically by this method, and the relationships of these organisms to the frankiae need to be made clearer. In addition, 16S rRNA sequencing of type A Frankia strains should also be performed. Type A strains are currently classified in the genus Frankia along with type B strains on the basis of morphology and ecology, but may be as different from type B strains as the genus Rhizobium is from the genus Bradyrhizobium. The LFRFA and DNA-DNA relatedness studies need to be expanded to include isolates obtained from host plants other than Alnus spp., Myrica spp. and members of the Casuarinaceae and Elaeagnaceae, where the main emphasis has been until now. As the host plant of origin appears to be a very important element in Frankia species delineation, as shown by hypervariable 16S rRNA sequences, DNA-DNA relatedness data, and LFRFA data, it is imperative that the effect of repeated plant passages in a given host or several different hosts on the stability of these criteria be determined.

Frankia taxonomists, like other workers dealing with difficult-to-grow organisms, are likely to have to deal with day-to-day problems of classification at the molecular, not phenotypic, level. The proposal of Wayne et al. (96) that phenotypic tests which reflect molecular reality should be developed is probably not possible for this taxon. It is well within our technological grasp to develop molecular tests which will enable us to obtain the answers that we need in a reasonable time. Frankia taxonomy, as stated above, is something of a model for microbial taxonomy. The constraints that microbial groups like the genus Frankia impose force us to develop techniques that will undoubtedly benefit all taxonomy in the future.

\section{ACKNOWLEDGMENTS}

The comments of Beth Mullin, Dwight Baker, and H. A. Lechevalier are greatly appreciated. The invaluable assistance provided by the up-to-date bibliography compiled by Dwight Baker is gratefully acknowledged.

\section{REFERENCES}

1. Akimov, V. N., and S. V. Dobritsa. 1992. Grouping of Frankia strains on the basis of DNA relatedness. Syst. Appl. Microbiol. 15:372-379.

2. An, S. C., W. S. Riggsby, and B. C. Mullin. 1985. Restriction pattern analysis of genomic DNA of Frankia isolates. Plant Soil 87:43-48.

3. An, S. C., W. S. Riggsby, and B. C. Mullin. 1985. Relationships of Frankia isolates based on deoxyribonucleic acid homology studies. Int. J. Syst. Bacteriol. 35:140-146.

4. An, S. C., J. W. Wills, W. S. Riggsby, and B. C. Mullin. 1983. Deoxyribonucleic acid base composition of 12 Frankia isolates. Can. J. Bot. 61:2859-2862.

5. Baker, D., and N. G. Miller. 1980. Ultrastructural evidence for the existence of actinorhizal symbioses in the late Pleistocene. Can. J. Bot. 58:1612-1620.

6. Baker, D., and B. C. Mullin. 1991. Diversity of Frankia and the use of RFLP patterns to identify strains in nodules, p. 11 . Abstr. 8th Int. Conf. Frankia Actinorhizal Plants, Lyon, France.

7. Baker, D., W. L. Pengelly, and J. G. Torrey. 1981. Immunochemical analysis of relationships among the isolated frankiae (Actinomycetales). Int. J. Syst. Bacteriol. 31:148-151.

8. Baker, D. D. 1987. Relationships among pure-cultured strains 
of Frankia based on host specificity. Physiol. Plant. 70:245248.

9. Baker, D. D., and B. C. Mullin. 1992. Actinorhizal symbioses, p. 259-292. In G. Stacy, R. H. Burris, and H. J. Evans (ed.), Biological nitrogen fixation. Chapman and Hall, New York.

10. Baker, D. D., and C. R. Schwintzer. 1990. Introduction, p. 1-13. In C. R. Schwintzer and J. D. Tjepkema (ed.), The biology of Frankia and actinorhizal plants. Academic Press, San Diego, Calif.

11. Becking, J. H. 1970. Frankiaceae fam. nov. (Actinomycetales) with one new combination and six new species of the genus Frankia Brunchorst 1886, 1974. Int. J. Syst. Bacteriol. 20:201220.

12. Becking, J. H. 1974. Family III. Frankiaceae Becking 1970, 201, p. 701-706. In R. E. Buchanan and N. E. Gibbons (ed.), Bergey's manual of determinative bacteriology, 8 th ed. The Williams and Wilkins Co., Baltimore.

13. Benoist, P., and J. Schwencke. 1990. Native agarose-polyacrylamide gel electrophoresis allowing the detection of aminopeptidase, dehydrogenase and esterase activities at the nanogram level: enzymatic patterns in some Frankia strains. Anal. Biochem. 187:337-344.

14. Benson, D. R., and D. Hanna. 1983. Frankia diversity in an alder stand as estimated by SDS-PAGE of whole cell protein. Can. J. Bot. 61:2919-2923.

15. Benson, D. R., and W. B. Silvester. 1993. Biology of Frankia strains, actinomycete symbionts of actinorhizal plants. Microbiol. Rev. 57:293-319.

16. Berry, A. M., R. A. Moreau, and A. D. Jones. 1991. Bacteriohopanetetrol: abundant lipid in Frankia cells and in nitrogenfixing nodule tissue. Plant Physiol. 95:111-115.

17. Beyazova, M., and M. P. Lechevalier. 1992. Low-frequency restriction fragment analysis of Frankia strains (Actinomycetales). Int. J. Syst. Bacteriol. 42:422-433.

18. Bloom, R. A., B. C. Mullin, and R. L. Tate. 1989. DNA hybridization studies of Frankia isolates from Myrica pensylvanica (bayberry). Appl. Environ. Microbiol. 55:2155-2160.

19. Bosco, M., M. P. Fernandez, P. Simonet, R. Materassi, and P. Normand. 1992. Evidence that some Frankia sp. strains are able to cross boundaries between Alnus and Elaeagnus host specificity groups. Appl. Environ. Microbiol. 58:1569-1576.

20. Brunchorst, J. 1886. Ueber einige Wurzelanschwellungen, besonders diejenigen von Alnus und den Elaeagnaceen. Bot. Inst. Tubingen 2:151-177.

21. Callaham, D., P. Del Tredici, and J. G. Torrey. 1978. Isolation and cultivation in vitro of the actinomycete causing roo nodulation in Comptonia. Science 199:899-902.

22. Chen, L., Y. Cui, M. Qin, Y. Wang, X. Bai, and Q. Ma. 1991. Identification of a nod D-like gene in Frankia by direct complementation of a Rhizobium nod D mutant. Mol. Gen. Genet. 233:311-314.

23. Dazhi, D., and D. D. Baker. 1992. Actinorhizal host-specificity of Chinese Frankia strains. Plant Soil 144:113-116.

24. Dazzo, F. B., and A. E. Gardiol. 1984. Host specificity in Rhizobium-legume interactions, p. 3-31. In D. P. S. Verma and $\mathrm{T}$. Hohn (ed.), Genes involved in microbe-plant interactions. Springer-Verlag, Vienna.

25. Dobritsa, S. V. 1985. Restriction analysis of the Frankia spp. genome. FEMS Microbiol. Lett. 29:123-128.

26. Dobritsa, S. V., S. N. Novik, and O. S. Stupar. 1990. Infectivity and host specificity of strains of Frankia. Microbiology (Engl. Transl. Mikrobiologiya) 59:210-214.

27. Dobritsa, S. V., and O. S. Stupar. 1989. Genetic heterogeneity among Frankia isolates from root nodules of individual actinorhizal plants. FEMS Microbiol. Lett. 58:287-292.

28. Faure-Raynaud, M., M. A. Bonnefoy-Poirier, and A. Moiroud. 1990. Diversity of Frankia strains isolated from actinorhizae of a single Alnus rubra cultivated in nursery. Symbiosis 8:147160.

29. Faure-Raynaud, M., C. Danière, and A. Moiroud. 1991. Evaluation of strain preference by four different Alnus glutinosa genotypes on a Frankia soil population, p. 18. Abstr. 8th Int. Conf. Frankia Actinorhizal Plants, Lyon, France.
30. Faure-Raynaud, M., and A. Moiroud. 1983. Symbiose Frankiaaulnes: culture in vitro de Frankia sp. sur différentes sources de carbone et d'azote. C. R. Acad. Sci. 296:757-760.

31. Fernandez, M. P., H. Meugnier, P. A. D. Grimont, and R. Bardin. 1989. Deoxyribonucleic acid relatedness among members of the genus Frankia. Int. J. Syst. Bacteriol. 39:424429.

32. Fernandez, M. P., S. Nazaret, P. Simonet, B. Cournoyer, and P. Normand. 1991. Structure of the genus Frankia, p. 629-633. In M. Polsinelli, R. Materassi, and M. Vincenzi (ed.), Nitrogen fixation. Kluwer Academic Publishers, Dordrecht, The Netherlands.

33. Gadkari, D., G. Mörsdorf, and O. Meyer. 1992. Chemolithoautotrophic assimilation of dinitrogen by Streptomyces thermoautotrophicus UBT 1: identification of an unusual $\mathrm{N}_{2}$-fixing system. J. Bacteriol. 174:6840-6843.

34. Gardes, M., J. Bousquet, and M. Lalonde. 1987. Isozyme variation among 40 Frankia strains. Appl. Environ. Microbiol. 53:1596-1603.

35. Gardes, M., and M. Lalonde. 1987. Identification and subgrouping of Frankia strains using sodium dodecyl sulfatepolyacrylamide gel electrophoresis. Physiol. Plant. 70:237244.

36. Goodfellow, M. 1971. Numerical taxonomy of some nocardioform bacteria. J. Gen. Microbiol. 69:33-80.

37. Hahn, D., M. Dorsch, E. Stackebrandt, and A. D. L. Akkermans. 1989. Synthetic oligonucleotide probes for identification of Frankia strains. Plant Soil 118:211-219.

38. Hahn, D., R. Kester, M. J. C. Starrenburg, and A. D. L. Akkermans. 1990. Extraction of ribosomal RNA from soil for detection of Frankia with oligonucleotide probes. Arch. Microbiol. 154:329-335.

39. Hahn, D., M. P. Lechevalier, A. Fischer, and E. Stackebrandt. 1989. Evidence for a close phylogenetic relationship between members of the genera Frankia, Geodermatophilus and "Blastococcus" and emendation of the family Frankiaceae. Syst. Appl. Microbiol. 11:236-242.

40. Harriott, O. T., L. Khairallah, and D. R. Benson. 1991. Isolation and structure of the lipid envelopes from nitrogenfixing vesicles of Frankia sp. strain CpI1. J. Bacteriol. 173: 2061-2067.

41. Harry, D. E., D. C. Yang, and J. O. Dawson. 1991. Nucleotide sequence and diversity in 16S ribosomal RNA from Frankia. Plant Soil 131:143-146.

42. Horrière, F. 1984. In vitro physiological approach to classification of Frankia isolates of "the Alnus group" based on urease, protease and $\beta$-glucosidase activities. Plant Soil 78:713.

43. Jamann, S., M. P. Fernandez, and A. Moiroud. 1992. Genetic diversity of Elaeagnaceae-infective Frankia strains isolated from various soils. Acta Oecologica 13:395-405.

44. Jamann, S., M. P. Fernandez, and P. Normand. 1993. Typing method for $\mathrm{N}_{2}$-fixing bacteria based on PCR RFLP-application to the characterization of Frankia strains. Mol. Ecol. 2:17-26.

45. Jurtshuk, P., R. Knapp, and M. P. Lechevalier. 1990. Taxonomic assessment of free-living diazotrophic actinomycete isolates, Streptomyces strains NPLC and OTLC, abstr. R-17, p. 248. Abstr. 90th Annu. Meet. Am. Soc. Microbiol. 1990.

46. Lalonde, M., L. Simon, J. Bousquet, and A. Séguin. 1988. Advances in the taxonomy of Frankia: recognition of species alni and elaeagni and novel subspecies pommerii and van dijkii, p. 671-680. In H. Bothe, F. J. de Bruijn, and W. E. Newton (ed.), Nitrogen fixation: hundred years after. Gustav Fischer Verlag, New York.

47. Lechevalier, M. P. Unpublished data.

48. Lechevalier, M. P. 1983. Cataloging Frankia strains. Can. J. Bot. 61:2964-2967.

49. Lechevalier, M. P. 1984. The taxonomy of the genus Frankia. Plant Soil 78:1-6.

50. Lechevalier, M. P. 1986. Nitrogen-fixing actinomycetes of the genus Frankia, p. 253-256. In F. Megusar and M. Gantar (ed.), Perspectives in microbial ecology. Slovene Society for Micro- 
biology, Ljubljana, Yugoslavia.

51. Lechevalier, M. P., D. Baker, and F. Horrière. 1983. Physiology, chemistry, serology and infectivity of two Frankia isolates from Alnus incana subsp. rugosa. Can. J. Bot. 61:2826-2833.

52. Lechevalier, M. P., and H. A. Lechevalier. 1979. The taxonomic position of the actinomycete endophytes, p. 111-121. In J. C. Gordon, C. T. Wheeler, and D. A. Perry (ed.), Symbiotic nitrogen fixation in the management of temperate forests. Oregon State University Forest Research Laboratory, Corvallis.

53. Lechevalier, M. P., and H. A. Lechevalier. 1980. The chemotaxonomy of actinomycetes, p. 227-291. In A. Dietz and D. W. Thayer (ed.), Actinomycete taxonomy. Society for Industrial Microbiology Special Publication 6. Society for Industrial Microbiology, Arlington, Va.

54. Lechevalier, M. P., and H. A. Lechevalier. 1989. Genus Frankia Brunchorst $1886,174^{\mathrm{AL}}$, p. $2410-2417$. In S. T. Williams, M. E. Sharpe, and J. G. Holt (ed.), Bergey's manual of systematic bacteriology, vol. 4. The Williams and Wilkins Co., Baltimore.

55. Lechevalier, M. P., and H. A. Lechevalier. 1990. Systematics, isolation and culture of Frankia, p. 35-60. In C. R. Schwintzer and J. D. Tjepkema (ed.), The biology of Frankia and actinorhizal plants. Academic Press, San Diego, Calif.

56. Lechevalier, M. P., and J. S. Ruan. 1984. Physiology and chemical diversity of Frankia spp. isolated from nodules of Comptonia peregrina (L.) Coult. and Ceanothus americanus. Plant Soil 78:15-22.

57. Maggia, L., S. Nazaret, and P. Simonet. 1992. Molecular characterization of Frankia isolates from Casuarina equisetifolia root nodules harvested in West Africa (Senegal and Gambia). Acta Oecologica 13:453-461.

58. Maggia, L., Y. Prin, B. Picard, and P. Goullet. 1990. Esterase patterns of 60 isolates of Frankia from Casuarina equisetifolia grown in Senegambia, p. 141-148. In M. H. El-Lakany, J. W. Turnbull, and J. L. Brewbaker (ed.), Advances in Casuarina research. Desert Development Center, American University, Cairo.

59. Meesters, T. M., W. M. Van Vliet, and A. D. L. Akkermans. 1987. Nitrogenase is restricted to the vesicles in Frankia strain EAN $1_{\text {pec }}$. Physiol. Plant. 70:267-271.

60. Mirza, M. S., D. Hahn, and A. D. L. Akkermans. 1992. Isolation and characterization of Frankia strains from Coriaria nepalensis. Syst. Appl. Microbiol. 15:289-295.

61. Mirza, M. S., J. D. Janse, D. Hahn, and A. D. L. Akkermans. 1991. Identification of atypical Frankia strains by fatty acid analysis. FEMS Microbiol. Lett. 83:91-98.

62. Mishra, S. K., R. E. Gordon, and D. A. Barnett. 1980. Identification of nocardiae and streptomycetes of medical importance. J. Clin. Microbiol. 11:728-736.

63. Mort, A., P. Normand, and M. Lalonde. 1983. 2-O-methyl-Dmannose, a key sugar in the taxonomy of Frankia. Can. J. Microbiol. 29:993-1002.

64. Mullin, B. C., and C. S. An. 1990. The molecular genetics of Frankia, p. 195-214. In C. R. Schwintzer and J. D. Tjepkema (ed.), The biology of Frankia and actinorhizal plants. Academic Press, San Diego, Calif.

65. Mullin, B. C., S. M. Swensen, and P. Goetting-Minesky. 1990. Hypotheses for the evolution of actinorhizal symbioses, p. 781-787. In P. M. Gresshoff, L. E. Roth, G. Stacey, and W. E. Newton (ed.), Nitrogen fixation: achievements and objectives. Chapman and Hall, New York.

66. Nazaret, S., B. Cournoyer, P. Normand, and P. Simonet. 1991. Phylogenetic relationships among Frankia genomic species determined by use of amplified 16S rRNA sequences. J. Bacteriol. 173:4072-4078.

67. Nazaret, S., P. Simonet, P. Normand, and R. Bardin. 1989. Genetic diversity among Frankia isolates from Casuarina nodules. Plant Soil 118:241-247.

68. Nesme, X., P. Normand, F. M. Tremblay, and M. Lalonde. 1985. Nodulation speed of Frankia sp. on Alnus glutinosa, Alnus crispa and Myrica gale. Can. J. Bot. 63:1292-1295.

69. Nittayajarn, A., B. D. Mullin, and D. D. Baker. 1990. Screening of symbiotic frankiae for host specificity by restriction frag- ment length polymorphism analysis. Appl. Environ. Microbiol. 56:1172-1174.

70. Normand, P., and J. Bousquet. 1989. Phylogeny of nitrogenase sequences in Frankia and other nitrogen-fixing microorganisms. J. Mol. Evol. 29:436-447.

71. Normand, P., B. Cournoyer, P. Simonet, and S. Nazaret. 1992. Analysis of a ribosomal RNA operon in the actinomycete Frankia. Gene 111:119-124.

72. Normand, P., M. Gouy, B. Cournoyer, and P. Simonet. 1992. Nucleotidue sequence of nif $D$ from Frankia alni strain ArI3; phylogenetic inferences. Mol. Biol. Evol. 9:495-506.

73. Normand, P., and M. Lalonde. 1982. Evaluation of Frankia strains isolated from provenances of two Alnus species. Can. J. Microbiol. 28:1133-1142.

74. Normand, P., P. Simonet, and R. Bardin. 1988. Conservation of nif sequences in Frankia. Mol. Gen. Genet. 213:238-246.

75. Normand, P., P. Simonet, J. L. Butour, C. Rosenberg, A. Moiroud, and M. Lalonde. 1983. Plasmids in Frankia sp. J. Bacteriol. 155:32-35.

76. Paget, E., and P. Simonet. 1991. Characterization of some Frankia strains nodulating Coriaria plants by direct sequencing of amplified DNA, p. 16. Abstr. 8th Int. Conf. Frankia Actinorhizal Plants, Lyon, France.

77. Parsons, R., W. B. Silvester, S. Harris, W. T. M. Gruijters, and S. Bullivant. 1987. Frankia vesicles provide inducible and absolute oxygen protection for nitrogenase. Plant Physiol. 83:728-731.

78. Reddy, A., B. Bochenek, and A. M. Hirsch. 1992. A new Rhizobium meliloti symbiotic mutant isolated after introducing Frankia DNA sequence into a nodA::Tn5 strain. Mol. PlantMicrobe Interact. 5:62-71.

79. Rouvier, C., S. Nazaret, M. P. Fernandez, B. Picard, P. Simonet, and P. Normand. 1992. $r m$ and nif intergenic spacers and isozyme patterns as tools to characterize Casuarinainfective Frankia strains. Acta Oecologica 13:487-495.

80. Ruan, J.-S., M. P. Lechevalier, and D. D. Baker. 1992. Thin layer chromatographic analysis of whole-cell sugar patterns of Chinese Frankia strains. Acta Oecologica 13:417-422.

81. Séguin, A., and M. Lalonde. 1989. Detection of pectolytic activity and pel homolgous sequences in Frankia. Plant Soil 118:221-229.

82. Shi, Y., and J. Ruan. 1990. Study of Frankia in Xishuangbanna, p. 207-215. In Proceedings of the International Workshop on Research on Multipurpose Tree Species in Asia, Los Banos, Philippines. Winrock International Institute for Agricultural Development, Bangkok.

83. Shi, Y., J. Ruan, J. Zakrzewska-Czerwinska, and M. Mordarski. 1991. DNA homology of some Frankia strains. Actinomycetes (NS) 2:86-87.

84. Shipton, W. A., and A. J. P. Burggraaf. 1982. A comparison of the requirements of various carbon and nitrogen sources and vitamins in some Frankia isolates. Plant Soil 69:149-161.

85. Shirling, E. B., and D. Gottlieb. 1972. Cooperative description of type strains of Streptomyces. Int. J. Syst. Bacteriol. 22:265394.

86. Simon, L., J. Bousquet, M. Gardes, L. St-Laurent, and M. Lalonde. 1988. Competitiveness of Frankia strains on Elaeagnus clonal plantlets. FEMS Microbiol. Lett. 51:13-18.

87. Simon, L., S. Jabaji-Hare, J. Bousquet, and M. Lalonde. 1989. Confirmation of Frankia species using cellular fatty acid analysis. Syst. Appl. Microbiol. 11:229-235.

88. Simonet, P., M.-C. Grosjean, A. K. Misra, S. Nazaret, B. Cournoyer, and P. Normand. 1991. Frankia genus-specific characterization by polymerase chain reaction. Appl. Environ. Microbiol. 57:3278-3286.

89. Simonet, P., P. Normand, A. M. Hirsch, and A. D. L. Akkermans. 1990. The genetics of the Frankia actinorhizal symbiosis, p. 77-109. In P. M. Gresshoff (ed.), The molecular biology of symbiotic nitrogen fixation. CRC Press, Boca Raton, Fla.

90. Simonet, P., P. Normand, A. Moiroud, and R. Bardin. 1990. Identification of Frankia strains in nodules by hybridization of polymerase chain reaction products with strain-specific oligonucleotide probes. Arch. Microbiol. 153:235-240. 
91. Simonet, P., P. Normand, A. Moiroud, and M. Lalonde. 1984. Restriction enzyme digestion patterns of Frankia plasmids. Plant Soil 87:49-60.

92. Simonet, P., N. Thi Le, A. Moiroud, and R. Bardin. 1989. Diversity of Frankia strains isolated from a single alder stand. Plant Soil 118:13-22.

93. Stackebrandt, E. 1985. Phylogeny and phylogenetic classification of prokaryotes, p. 309-334. In K. H. Schleifer and E. Stackebrandt (ed.), Evolution of prokaryotes. Academic Press, London.

94. St-Laurent, L., J. Bousquet, L. Simon, and M. Lalonde. 1987. Separation of various Frankia strains in the Alnus and Elaeagnus host specificity groups using sugar analysis. Can. J. Microbiol. 33:764-772.

95. Van Dijk, C. 1978. Spore formation and endophyte diversity in root nodules of Alnus glutinosa (L.) Vill. New Phytol. 81:601615.

96. Wayne, L. G., D. J. Brenner, R. R. Colwell, P. A. D. Grimont, O. Kandler, M. I. Krichevsky, L. H. Moore, W. E. C. Moore, R. G. E. Murray, E. Stackebrandt, M. P. Starr, and H. G. Trüper. 1987. Report of the Ad Hoc Committee on Reconciliation of Approaches to Bacterial Systematics. Int. J. Syst. Bacteriol. 37:463-464.
97. Weber, A., A. Smolander, E.-L. Nurmiaho-Lassila, and V. Sundman. 1988. Isolation and characterization of Frankia strains from Alnus incana and Alnus glutinosa in Finland. Symbiosis 6:97-116.

98. Wheeler, C. T., J. E. Hooker, A. Crose, and A. M. M. Berrie. 1986. The improvement and utilization in forestry of nitrogen fixation by actinorhizal plants with special reference to Alnus in Scotland. Plant Soil 90:393-406.

99. Williams, S. T., M. Goodfellow, G. Alderson, E. M. H. Wellington, P. H. A. Sneath, and M. J. Sacklin. 1983. Numerical classification of Streptomyces and related genera. J. Gen. Microbiol. 129:1743-1813.

100. Woronin, M. 1866. Ueber die bei der Schwarzerle (Alnus glutinosa) und der gewöhnlichen Garten-Lupine (Lupinus mutabilis) auftretenden Wurzelanschwellungen. Mem. Acad. Sci. St. Petersburg Ser. 7 10:1-10.

101. Young, J. P. W. 1992. Phylogenetic classification of nitrogenfixing organisms, p. 43-86. In G. Stacey, R. H. Burns, and H. J. Evans (ed.), Biological nitrogen fixation. Chapman and Hall, New York.

102. Zhang, Z., M. F. Lopez, and J. G. Torrey. 1984. A comparison of cultural characteristics and infectivity of Frankia isolates from root nodules of Casuarina species. Plant Soil 78:79-90. 